Journal Wetenskap Health

\title{
The Relation Between Work Motivation and Nurse Performance of Inpatient Installations at Methodist General Hospital Medan
}

\author{
Arifin Chandra ${ }^{1}$, Mangatas Silaen ${ }^{2}$, Jamaluddin ${ }^{2}$ \\ ${ }^{1}$ Master of Public Health, Helvetia Institute of Health, Indonesia \\ ${ }^{2}$ Helvetia Institute of Health Medan Research Group, Indonesia
}

\begin{abstract}
Motivation is defined as something in a person that can be pushed, and direct person behaviour. In other word, motivation is intentions in ourself, hope, desire and purposed to be achieved. Nurses have an important role in determining good or bad quality hospital service. Motivation owned by nurses is important as a force spesifically to provide health service to health service users in the hospital. This research is quantitative and using cross sectional design. The purpose of this research is to see what factors that can related over the performance of nurses of emergency room in Methodist Hospital Medan 2018. This research use total sampling and the source data of this research is using questionnaire and then followed by using univariate analysis, bivariate analysis, multivariate analysis with SPSS program. The results of this research is that responsibility $(p=0,004)$, supervision $(p=0,001)$, insentive $(p=0,003)$, achievement $(\mathrm{p}=0,002)$, promotion $(\mathrm{p}=0,004)$, related to nurse performance and the most related variable is supervision with $\mathrm{r}$ square $0,026, \mathrm{~F}=1,279$, and sign $\mathrm{F} 95 \% \mathrm{CI}=0,264$. The result showed that there related between motivation and nurse performance. The most related factor is supervision. Supervision done by head of nursing routinely to all nurse. In order optimize performance, quality and health services increase the motivation for this to work and to the way of administering the able more, creates an enabling environment, companion at good relations with, guarantee work, good relations between superiors with subordinate, and including nurse in seminars and sustainable trainings nursing.
\end{abstract}

Keywords: Nurse Performance, Responsibility, Supervision, Promotion

\section{Introduction}

Nurses have a very important role in determining the good or bad quality of the hospital because nurses are the human resources who have the most direct contact with patients. In providing health services to patients, nurses have the motivation to encourage nurses to provide the best service. Nurse motivation is a very important component for nurses in providing services to patients. The motivation possessed by nurses is a special encouragement to provide health services to users of health services in hospitals.

Motivation can come from internal and external encouragement. Nursing services contribute to determining the quality of hospital services, so that every effort to improve the quality of hospital services must also be accompanied by efforts to improve the quality of nursing services, one of which is by increasing the performance of nurses (Abdullah et al., 2013).

\section{Methods}

This research is quantitative and using cross sectional design. The purpose of this research is to see what factors that can related over the performance of nurses of emergency room in Methodist Hospital Medan 2018. This research use total sampling and the source data of this 
research is using a questionnaire and then followed by using univariate analysis, bivariate analysis, multivariate analysis with SPSS program.

\section{Results and Discussion}

Table 1. Distribution of Respondents by Gender

\begin{tabular}{|l|l|l|r|}
\hline No & Sex & Frequency (f) & \% \\
\hline 1 & Male & 12 & 24,0 \\
\hline 2 & Femlae & 38 & 76,0 \\
\hline \multicolumn{2}{|c|}{ Total } & $\mathbf{5 0}$ & $\mathbf{1 0 0}$ \\
\hline
\end{tabular}

Based on the table above the distribution of respondents based on gender, the majority are women as many as 38 people $(76 \%)$ and men as many as 12 people $(24 \%)$.

Table 2. Distribution of Respondents by Age

\begin{tabular}{|l|l|l|l|}
\hline No & \multicolumn{1}{c|}{ Age } & Frequency $(\mathbf{f})$ & \multicolumn{1}{c|}{$\%$} \\
\hline 1 & $<30$ years & 19 & 38,0 \\
\hline 2 & $30-40$ years & 29 & 58,0 \\
\hline 3 & $41-50$ years & 2 & 4,0 \\
\hline \multicolumn{2}{|c|}{ Total } & $\mathbf{5 0}$ & $\mathbf{1 0 0}$ \\
\hline
\end{tabular}

Based on the table above, the distribution of respondents based on age is dominated by the $30-40$ year old group totaling 29 people $(58 \%)$. Meanwhile, there were 19 people aged $<30$ years $(38 \%)$ and the $41-50$ years age group 2 people (4\%).

Table 3. Distribution of Respondents by Education

\begin{tabular}{|c|l|l|c|}
\hline No & Education & Frequency (f) & \% \\
\hline 1 & D3/Diploma & 41 & 82,0 \\
\hline 2 & S1/Bachelor & 9 & 18,0 \\
\hline \multicolumn{2}{|c|}{ Total } & $\mathbf{5 0}$ & $\mathbf{1 0 0}$ \\
\hline
\end{tabular}

Based on the table above, the distribution of respondents based on education is dominated by the DIII Nursing education level totaling 41 people (82\%) while for the S1 education level there are 9 people $(18 \%)$.

Table 4. Distribution of Respondents by Income

\begin{tabular}{|l|l|l|l|}
\hline \multicolumn{1}{|c|}{ No } & Income & Frequency (f) & \% \\
\hline 1 & $<2.700 .000$ & 32 & 64,0 \\
\hline 2 & $>2.700 .000$ & 18 & 36,0 \\
\hline Total & & $\mathbf{5 0}$ & $\mathbf{1 0 0}$ \\
\hline
\end{tabular}

Based on the table above, the distribution of respondents based on income is dominated by income $<2,700,000$ totaling 32 people (64\%), while for income $>2,700,000$, it is 18 people $(36 \%)$.

Table 5. Distribution of Respondents Distribution Based on Marital Status

\begin{tabular}{|l|l|l|r|}
\hline No & Marriage Status & Frequency (f) & \% \\
\hline 1 & Not mArried & 23 & 46,0 \\
\hline 2 & Married & 27 & 54,0 \\
\hline \multicolumn{2}{|c|}{ Total } & $\mathbf{5 0}$ & $\mathbf{1 0 0}$ \\
\hline
\end{tabular}

Berdasarkan tabel diatas distribusi responden berdasarkan status pernikahan didominasi oleh status menikah berjumlah 27 orang (54\%) sedangkan untuk yang belum menikah 
berjumlah 23 orang (46\%).

Table 6. Distribution of Respondents Distribution Based on Length of Work

\begin{tabular}{|c|l|l|l|}
\hline No & Length of work & (f) & \% \\
\hline & $<5$ years & 24 & 48 \\
\hline & 5-10 years & 22 & 44 \\
\hline & $>10$ years & 4 & 8 \\
\hline & Total & $\mathbf{5 0}$ & $\mathbf{1 0 0}$ \\
\hline
\end{tabular}

Based on the table above, the distribution of respondents based on length of work is dominated by working time $<5$ years totaling 24 people $(48 \%)$, for working time 5-10 years amounted to 22 people (44\%), while for working hours> 10 years totaled 4 people $(8 \%)$.

\section{Univariate Analysis}

Table 7. Frequency Distribution of Responsibility Variables

\begin{tabular}{|c|l|l|l|}
\hline No & Responsibility & (f) & \multicolumn{1}{|c|}{$\%$} \\
\hline 1 & Bad & 1 & 2,0 \\
\hline 2 & Medium & 11 & 22,0 \\
\hline 3 & Good & 38 & 76,0 \\
\hline \multicolumn{2}{|c|}{ Total } & $\mathbf{5 0}$ & $\mathbf{1 0 0}$ \\
\hline
\end{tabular}

Based on the table above, the frequency distribution of the responsibility variable is dominated by a good level of responsibility totaling 38 people $(76 \%), 11$ people $(22 \%)$ for a moderate level of responsibility, 1 person $(2 \%)$ for a bad level of responsibility.

Tabel 8. Distribusi Frekuensi Variabel Supervisi

\begin{tabular}{|c|c|c|c|}
\hline No & Responsibility & (f) & \% \\
\hline 1 & Bad & 4 & 8,0 \\
\hline 2 & Medium & 19 & 38,0 \\
\hline 3 & Good & 27 & 54,0 \\
\hline \multicolumn{2}{|c|}{ Total } & $\mathbf{5 0}$ & $\mathbf{1 0 0}$ \\
\hline
\end{tabular}

Based on the table above, the frequency distribution of the supervision variable is dominated by a good level of supervision totaling 27 people $(54 \%)$, for the moderate level of supervision there are 19 people (38\%), while for the poor level of supervision there are 4 people $(8 \%)$.

Table 9. Frequency Distribution of Incentive Variables

\begin{tabular}{|c|c|c|c|}
\hline No & Responsibility & (f) & \% \\
\hline 1 & Buruk & 4 & 8,0 \\
\hline 2 & Sedang & 19 & 38,0 \\
\hline 3 & Baik & 27 & 54,0 \\
\hline & Total & $\mathbf{5 0}$ & $\mathbf{1 0 0}$ \\
\hline
\end{tabular}

dominated by good achievement amounted to 27 people (54\%), for moderate achievement amounted to 19 people (38\%), while for poor performance amounted to 4 people $(8 \%)$.

Table 10. Frequency Distribution of Promotion Variables

\begin{tabular}{|l|l|c|c|}
\hline No & Responsibility & Frekuensi (f) & \% \\
\hline 1 & Low & 6 & 12,0 \\
\hline 2 & Medium & 15 & 30,0 \\
\hline
\end{tabular}




\begin{tabular}{|c|c|c|}
\hline \multirow{2}{*}{\begin{tabular}{l|l}
3 & High \\
Total
\end{tabular}} & 29 & 58,0 \\
\hline & 50 & 100 \\
\hline
\end{tabular}

Based on the table above, the frequency distribution of the incentive variable is dominated by high incentives totaling 29 people (58\%), for moderate incentives there are 15 people (30\%), while for low incentives there are 6 people (12\%).

Table 11. Frequency Distribution of Performance Variables

\begin{tabular}{|c|l|c|c|}
\hline No & Incentive & (f) & \% \\
\hline 1 & Low & 11 & 27,5 \\
\hline 2 & Medium & 10 & 25,0 \\
\hline 3 & Good & 19 & 47,5 \\
\hline \multicolumn{2}{|c|}{ Total } & $\mathbf{4 0}$ & $\mathbf{1 0 0}$ \\
\hline
\end{tabular}

Based on the table above, the frequency distribution of the promotion variable is dominated by a good level of promotion totaling 27 people $(54 \%)$, for a moderate level of promotion there are 19 people (38\%), while for bad promotions there are 4 people $(8 \%)$.

Table 12. Frequency Distribution of Nurse Performance

\begin{tabular}{|c|l|l|l|}
\hline No & \multicolumn{1}{|c|}{ Variable } & $(\mathbf{r})$ & P value \\
\hline 1 & Low & 2 & 4,0 \\
\hline 2 & Medium & 28 & 56,0 \\
\hline 3 & Good & 20 & 40,0 \\
\hline \multicolumn{2}{|c|}{ Total } & $\mathbf{5 0}$ & $\mathbf{1 0 0}$ \\
\hline
\end{tabular}

Based on the table above, the frequency distribution of nurses' performance is dominated by the performance of nurses who are currently 28 people $(56 \%)$, for good performance of nurses there are 20 people (40\%), while for poor performance of nurses there are 2 people (4\%).

\section{Bivariate Analysis}

Table 13. Relationship of Responsibilities to Nurse Performance

\begin{tabular}{|c|l|l|}
\hline Variable & Pearson correlation (r) & P-value \\
\hline Responsibily & 0,455 & 0,004 \\
\hline
\end{tabular}

Based on the table above the responsibility variable has $r=0.455$ with $p$ value $=0.004$. Responsibility has a moderate, significant and positive relationship with nurse performance, meaning that the greater the responsibility given to nurses, the better the nurse's performance.

In line with research conducted by Murniyati et al. (2013) with the Fisher's Exact test results obtained a $\mathrm{p}$ value of 0.021 which indicates that there is a relationship between responsibility and the performance of the nurse.

This is in line with research conducted by Irena (2017) based on the results of the Pearson Correlation Test using the help of a data processing application, the Pearson Correlation value between the relationship of responsibility and nurse performance is 0.416 with a Sig value. (2tailed $)=0.000$. A variable is said to be significantly related if its significance value is less than the $5 \%$ probability level (0.05). This means that if the responsibility of a nurse is increased, the performance of the nurse will also increase.

Table 14. The Relationship between Supervision and Performance of Nurses

\begin{tabular}{|l|l|l|}
\hline Variable & Pearson correlation $(\mathbf{r})$ & P value \\
\hline
\end{tabular}




\begin{tabular}{|l|l|l|}
\hline Supervisi 0,674 & 0,001 \\
\hline
\end{tabular}

Based on the table above, the independent sub variable supervision has $r=0.674$ with $p$ value $=0.001$. Supervision has a moderate, significant and positive relationship with nurse performance, meaning that the greater the supervision given to nurses, the better the nurse's performance.

This is in line with research conducted by Irena (2017), based on the results of the Pearson Correlation test, a significant value of 0.008 was obtained which is smaller than the 5\% probability level $(0.000<0.05)$. So with these results it can be interpreted that supervision has a significant (real / significant) relationship to the performance of nurses. From the results of the Pearson Correlation test, it can be seen that if the level of supervision of a nurse increases, the performance it has will also increase, and vice versa, the lower the level of supervision the nurse has, the performance will also decrease.

In line with the research conducted by Nur (2013) with the results of statistical tests using chi-square, the value of $p=0.002$ was obtained, because the $p$ value $<0.05$ then Ho was rejected, which means that there is a significant relationship between supervision and the performance of the nurse in implementing patient safety Hasanuddin University Hospital inpatient room. In addition, through the phi and cremer tests, it was found that the relationship between variables was in the medium category.

Andriani (2012) states that supervision is an effort to assist in fostering and increasing the ability of those under supervision so that they can carry out their assigned activities efficiently and effectively.

Table 15. Relationship of Incentives to Nurse Performance

\begin{tabular}{|l|c|l|}
\hline Variable & Pearson correlation (r) & P-value \\
\hline Incentive & 0,4999 & 0,003 \\
\hline
\end{tabular}

Based on the table above, the independent sub incentive variable has $r=0.4999$ with $p$ value $=0.003$. Incentives have a moderate, significant and positive relationship with nurse performance, meaning that the greater the incentive given to nurses, the better the nurse's performance. This is in line with research conducted by Irena (2017) where the results of the Pearson Correlation test obtained a significant value of 0.000 which is smaller than the $5 \%$ probability level $(0.000<0.05)$. So with these results it can be interpreted that incentives have a significant relationship (real / meaningful) to the performance of nurses. From the results of the Pearson Correlation test, it can be seen that if the incentive level received by a nurse is increased, the performance it has will also increase, and vice versa, the lower the level of incentive received by nurses, the performance will also decrease because of this.

Theoretically, according to Susan (2019) incentives are all compensation received by employees in the form of financial compensation (remuneration) and non-financial compensation (promotion, transfer, praise, award). Incentives can be used as a tool to motivate employees to realize organizational goals, because incentives are a compensation approach by rewarding certain work results that employees have achieved.

Table 16. Relationship between Achievement and Nurse Performance

\begin{tabular}{|c|c|c|}
\hline Variable & Pearson correlation (r) & P-value \\
\hline Achievement & 0,572 & 0,002 \\
\hline
\end{tabular}

Based on the table above, the independent sub-variable of achievement has $r=0.572$ with $\mathrm{p}$ value $=0.002$. Achievement has a significant and positive relationship with nurse 
performance, meaning that the greater the achievement given to nurses, the better the nurse's performance. In line with the results of Nurjahjani's (2007) research on the effect of financial rewards, interpersonal rewards, and promotions on employee work performance, the results of the study concluded that work performance affects job promotion, by increasing an employee's performance, the higher the promotion. Achievement is one of the factors that influence nurses' motivation to improve performance. However, it is different from the research results of Suryono et al. (2018) stated that there is no relationship between work performance appraisals and employee performance.

Table 17. The Relationship between Promotion and Performance of Nurses

\begin{tabular}{|c|c|c|}
\hline Variable & Pearson correlation (r) & P-value \\
\hline Promotion & 0,772 & 0,004 \\
\hline
\end{tabular}

Based on the table above, the independent sub variable promotion has $r=0.772$ with $p$ value $=0.004$. Promotion has a significant and positive relationship with nurse performance, meaning that the greater the promotion given to nurses, the better the nurse's performance.

The results obtained are in accordance with the results of research conducted by Agus (2013) which found a significant relationship between job promotion and the performance of health workers in Polmas Regency. Promotion is one of the motivators. Promotion is an encouragement to achieve because you want a promotion or an increase in status as a form of appreciation from the leadership for good performance.

Table 18. The Effect of Supervision on Nurse Performance

\begin{tabular}{|c|c|c|c|}
\hline Variable & R Square & F & Sign. F (95\% CI) \\
\hline Supervision & 0,026 & 1,279 & 0,264 \\
\hline
\end{tabular}

Based on table 18, the supervision sub-variable has an $\mathrm{r}$ square value of 0.026 and an $\mathrm{F}$ value of 1.279 with a Sign.F value with a 95\% CI 0.264. The value of the supervision subvariable has the smallest $r$ square and F values with the Sign value. F is the highest. So it can be concluded that supervision is the most dominant subvariable and is related to nurse performance.

\section{Conclusion}

The results showed that most of the nurses were women, 30-40 years of age, nursing education, income $<2,700,000$, married and $<5$ years of service. Promotion sub variable and responsibility variable are the sub variables that are most related to nurse performance. There is a relationship between responsibility and nurse performance. With $r=0.455$ with $p$ value $=$ 0.004, which means that responsibility has a moderate, significant, and positive relationship with the performance of nurses, meaning that the greater the responsibility, the better the nurse's performance. There is a relationship between incentives and nurse performance. With the incentive $r=0.499$ with $\mathrm{p}$ value $=0.003$, which means that the incentive has a moderate, significant, and positive relationship with the nurse's performance, meaning that the greater the incentive given, the better the nurse's performance. There is a relationship between achievement and nurse performance. With $r=0.572$ with $p$ value $=0.002$, which means that achievement has a moderate, significant, and positive relationship with the performance of nurses, meaning that the higher the level of achievement, the better the nurse's performance. There is a relationship between supervision and nurse performance. With the result $r=0.672$ with $p$ value $=0.001$, which means that the higher the supervision, the better the nurse's performance. There is a relationship between promotion and nurse performance. With the result $r=0.772$ with $p$ value $=0.004$, which means that the greater the promotion given, the better the nurse's 
performance. Of all the variables that most influenced the nurse's performance was the variable r square value 0.026 and F value 1.279 with a Sign.F value with $95 \%$ CI 0.264 . The value of the supervision sub variable has the smallest $r$ square and $F$ values with the Sign value. F is the highest. So it can be concluded that supervision is the most dominant sub variable and is related to nurse performance.

\section{References}

Abdullah, A. Z., Hamzah, A., \& Mulyono, M. H. (2013). Faktor yang Berpengaruh terhadap Kinerja Perawat di Rumah Sakit Tingkat III 16.06. 01 Ambon. Jurnal Administrasi dan Kebijakan Kesehatan Indonesia, 2(01), 8270.

Agus M, A. H. (2013). Hubungan Motivasi Kerja dengan Kinerja Perawat di RSUD Sinjai (Saenab Dasong dan Eni Sutria) (Doctoral dissertation, Universitas Islam Negeri Alauddin Makassar).

Andriani, L. (2012). Kepuasan Kerja Perawat pada Aplikasi Metode Tim Primer dalam Pelaksanaan Tindakan Asuhan Keperawatan (Studi Kuantitatif di Rumah Sakit Dr. Saiful Anwar Malang). Jurnal Aplikasi Manajemen, 10(2), 419-424.

Irena, R. (2017). Hubungan Motivasi Dengan Kinerja Perawat Di Ruang Rawat Inap RSUD Dr. RM Pratomo Bagansiapapi Tahun 2017. Prepotif: Jurnal Kesehatan Masyarakat, l(2), 18-26.

Murniyati, A., Tilaar, C., \& Engkeng, S. (2013). Hubungan Antara Motivasi Kerja dengan Kinerja Perawat Pelaksana di Instalasi Rawat Inap a Badan Layanan Umum Rumah Sakit Umum Pusat prof. Dr. RD Kandou Manado. [serial on line].

Nur, Q. M. (2013). Hubungan motivasi dan supervisi terhadap kinerja perawat pelaksana dalam menerapkan patient safety di rawat inap RS Universitas Hasanuddin (Thesis Magister, Universitas Hasanudin). Retrieved from http://repository. unhas. ac. id.

Nurjahjani, F. (2007). Pengaruh Imbalan Ekstrinsik terhadap Prestasi Kerja (Studi Kasus pada Karyawan Bagian Pemasaran Asuransi Jiwa Bumi Asih Jaya Cabang Malang). Jurnal Ekonomi Modernisasi, 3(1), 28-42.

Suryono, L. K., Rumayar, A. A., \& Maramis, F. R. (2018). Hubungan Antara Prestasi Kerja Dan Perilaku Kerja Dengan Kinerja Pegawai Di Puskesmas Amurang Kabupaten Minahasa Selatan. Community Health, 2(6).

Susan, E. (2019). Manajemen sumber daya manusia. Adaara: Jurnal Manajemen Pendidikan Islam, 9(2), 952-962. 